\title{
THE APPLICATION OF INSTAGRAM ACTIVITY TO IMPROVE STUDENTS MOTIVATION IN ENGLISH SPEAKING
}

\author{
${ }^{1}$ Lisa Rakhmanina and ${ }^{2}$ Yuneva \\ ${ }^{1,2}$ English Education Department, Prof. Dr. Hazairin, SH University \\ lisarakhmanina83@gmail.com yuneva12@gmail.com
}

Received on Oct. 14th, Revised on Nov. 29th, Published on Dec. 30th 2018

\begin{abstract}
This study was aimed at finding out: (1) the significant difference in speaking achievement between the students who were trained with Instagram activity and those who were not; (2) the significant difference in motivation toward English Speaking between before and after the students were trained using Instagram Activity technique; (3) the interaction between teaching strategies and motivation toward students' speaking ability; and (4) the students' feedbacks concerning the Instagram Activity shown by the difference in students' speaking achievement. This study applied a quasi experimental study. The instruments used to find out the data were questionnaire and tests. The calculation of the study was applying descriptive and inferential analysis. The study result showed that Instagram activity in English speaking class was applied during the process of the teaching and learning in the classroom. It showed significant different on students` English achievement from pre-test to post-test between the students with low and high motivation. It means that Instagram activity could improve students` English speaking skill and could also motivate students to learn more.
\end{abstract}

Keywords: Instagram, motivation, speaking.

\begin{abstract}
ABSTRAK
Penelitian ini bertujuan untuk mengetahui: (1) perbedaan signifikan dalam prestasi berbicara antara siswa yang dilatih dengan aktivitas Instagram dan mereka yang tidak; (2) perbedaan yang signifikan dalam motivasi terhadap Berbicara Bahasa Inggris antara sebelum dan sesudah siswa dilatih menggunakan teknik Kegiatan Instagram; (3) interaksi antara strategi pengajaran dan motivasi terhadap kemampuan berbicara siswa; dan (4) umpan balik siswa mengenai Kegiatan Instagram yang ditunjukkan oleh perbedaan dalam prestasi berbicara siswa. Penelitian ini menerapkan penelitian quasi-eksperimental. Instrumen yang digunakan untuk mengetahui data adalah kuesioner dan tes. Perhitungan penelitian ini menggunakan analisis deskriptif dan inferensial. Hasil penelitian menunjukkan bahwa aktivitas Instagram di kelas berbahasa Inggris diterapkan selama proses belajar mengajar di kelas. Ini menunjukkan perbedaan yang signifikan pada prestasi belajar bahasa Inggris siswa dari pre-test ke post-test antara siswa dengan motivasi rendah dan tinggi. Ini berarti bahwa aktivitas Instagram dapat meningkatkan keterampilan berbahasa Inggris siswa dan juga dapat memotivasi siswa untuk belajar lebih banyak.
\end{abstract}

Kata kunci: Instagram, motivasi, berbicara. 


\section{INTRODUCTION}

Nowadays, internet has become an exploding passion in terms of modern technology. Internet is now a popular friend of every body. As the world is getting narrower, along with the borderless boundary of all nations in the world, internet comes as a tool responsible for the changes. Internet shows significant role in education as many today`s classes have many internets based instruments.

In English classroom, one of the latest approaches of teaching and learning English is by integrating technology in the classroom environment (Mutmainna, 2016). Through internet, people could text, chat, browse, call and make video call. Through internet people could also empower themselves through sharing stories in their own sites.

One facilities offered in the internet is Instagram. Instagram is photo and video sharing social media site (Herman, 2014). Ting (2014) states that many people have Instagram personal account nowadays. It was designed for mobile use with the intention that users would take photos on their mobile devices and upload the images 'instantly` through the Instagram app (Herman, 2014).

Instagram users are dominated by younger people, and that does not mean middle-aged could not have ones. Diamond
(2013) stated that in 2012, smartphone users spent more time on Instagram than on Twitter. Instagram has many of what other social medias have including the profile, followers, hashtags, push notifications, location tags, comments, likes, and chats (Wally \& Koshy, 2014). Instagram is mostly used by youngsters nowadays. It was reported that younger people used Instagram more than Facebook ((Solomon, 2013) as in (Ting, Run, Ming, Choo, 2015)).

Instagram comes with its simple and attractive performances. There are two main displays in Instagram that users could upload, i.e. photos and videos. There could be millions of photos and videos shared on Instagram that could be about travelling, business, personal activities, tutorials, and others.

This characteristics of Instagram attract people more to keep in touch. The push notification available offers time to people to be in with any moments. Nowadays, Instagram is mostly used in business area where many people try to market their products online. Instagram offers more interactive ways of marketing. As people could see the product displayed and comment on the purchased product. This create the product selling looks easier. Instagram is also found in other fields such 
as in academia (Solomon, 2013) and medical industry (Chante et al., 2014).

Instagram is one alternative way of teaching language. Taking into consideration that Instagram provides video tools, it becomes a further tool of teaching and learning media. According to Henich (1996) teachers are expected to be able to translate and channel learning to students through an intermediary or plural called the media and apply it with existing learning models. Instagram is a famous social media among youngsters. The eye catchy and easy use are two good reasons why youngsters fall in love with it. It is the reason why social media like Instagram is good for the teaching and learning process. According to Crowley (2015) there are some reasons to use social media in the classroom: (1) Social media provides venues for students to share their stories both within and beyond the classroom, (2) It also grants opportunities for them to hear stories from beyond their school, (3) Social media helps students to recognize the power of personal voice.

There are many activities that could be done by applying Instagram activity in the class, those are: reading, listening, writing and speaking activities. These four relates to the fouls skills in language learning. As a matter of fact, the speaking skill in learning a language is the one which is usually seen the first as a result. There are several speaking activities that could be conducted by using Instagram, which are: Role Play, Telling Experiences, Monologue (Tutorial, etc), Review, Pronunciation, and many others.

Speaking is the heart of learning English. Speaking as one productive skills offers a real result for someone who learn a foreign language. It is considered as the most important skill for business and government officers as it is the main communication tool worldwide. Speaking is extremely important when it comes to the output process of learning second language. Moreover, the teaching and evaluating of speaking is somewhat being ignored. It is also absent from the testing in every foreign language classroom since the objectivity of the testing is rather questioned. It should be raters who evaluate or judge the speaking ability of someone. Raters, not the teachers. The goal is the ability of language learners in orally express their ideas. Once speaking goals have been determined, next step consists of questioning how they are going to be achieved.

As a matter of fact, students tend to have lack of the ability in speaking language being learnt. They were seen having no desire to practice their English 
daily. English is being learnt since they were in early level of education. The fact that they still could not be able to speak in English is quit hard to accept.

According to Johnson and Pearson in Darmiyati (2007, p.16). There are two causes of low learning English speaking achievement. They are coming from external and internal factors. External factors can be classified into two groups: social and non-social factors. Social factors can come from the students themselves and non- social factors can be the place or location, the weather, and time when the learning process happens. Internal factors can also be classified into two groups. They are physiological factors and psychological factors. The physiological factors include the function of certain organs that students have. The psychological factors can be the students' motivation to read and interest.

This study discusses how motivation is important in learning English speaking. Instagram is considered a tool that could help students increasing their motivation in improving their English speaking skill.

\section{Problem Statements}

The problem statement of this study was formulated in the following questions: (1) was there any significant difference in speaking achievement between the students who are trained with Instagram activity and those who are not?; (2) was there any significant difference in motivation toward English Speaking between before and after the students are trained using Instagram Activity technique?; (3) was there any interaction between teaching strategies and motivation toward students' speaking ability; and (4) What were students' feedbacks concerning the Instagram Activity shown by the difference in students' speaking achievement?

\section{LITERATURE REVIEW}

The term webblog is a contraction of two words: web and log. Blogs are a tool for written communication and interaction. The term weblog refers to a personalized web page, kept by the author in reverse chronological diary form. As a "log on the web", it is kept first and foremost on the web, either on a static web page or via a database-backed website, enabled through blogging software. As a "log of the web", it easily refers to other Internet locations via hyperlinks (Simsek, 2009). Blogs are personal online journals which have recently become a collaborative technology and are regarded as a new way for people to express their thoughts in public (Nadzrah, 2009). This form of writing has become popular among Internet users. Most blog writers (bloggers) use this 
environment for self-expression and empowerment, as writing in blogs helps people become more thoughtful and critical in their writing (Blood, 2002). Blogging software encourages frequent site updates with the content, or 'micro-content', as Alexander (2006) prefers to name it, is presented in reverse chronological order. Hence, the micro-contents or posts are mainly composed of the blogger's own opinions and thoughts, showing why they are referred to as 'online diaries' (Hourigan \& Murray, 2010). Moreover, blogs can successfully promote self-expression in a place where the L2 learner/blogger is developing deeply personalized content dealing with their language learning (Murray \& Harrigan, 2008). Being both potentially individualistic and collaborative, blogs can transcend linguistic barriers and may be used for language learning purposes, where bloggers become part of a discourse community in a complex multimodal setting and learning together in collaborative spaces where people negotiate and construct meaning and texts (Raith, 2009). Blogs can also be used to publish and exchange personal knowledge.

\section{METHODOLOGY}

The method of the study was a quasi-experimental study. The action was the English speaking learning process that had been conducted by applying Instagram activities in Faculty of Economy, Bengkulu, Indonesia.

The subject of the study was students from Faculty of Economy, University of Prof. Hazairin, SH, Bengkulu, Indonesia. This study was conducted in the even semester in the academic year of 2017-2018.

\section{Data Collection Technique}

The data in this study were taken by the following techniques, they were as follows:

1. Motivation Questionnaire

The questionnaire is used to classify students into two groups, students who have high motivation and those who have low motivation. The researchers employed median to classify the sample. The students who had greater score than median were classified into high motivation students and the rest or the students who had less score than median were classified into low motivation students. The questionnaire consisted of statements about students' motivation. A Likert scale including four points scale instead of five points, in which the interval between each point on the scale is assumed to be equal is used here. The undecided point was omitted to avoid neutral 
answers, since mostly students tend to choose the neutral answer. It was used to register the extent of agreement or disagreement with a particular statement.

\section{Speaking Test}

it was used to have the students` study result. The tests were speaking test where students were asked to work in group and to perform one of the dialogue or monologue topic given. The performances from the pre test and two post tests of the two cycles were on Instagram and rated by the raters. The raters scored the students`English Speaking based on a Speaking Rubric

3. Feedback Questionnaire

Feedback questionnaire was delivered after the post test. It was applied to find out real opinion of the students toward the Instagram activity in speaking class.

\section{Data Analysis}

The technique used in analyzing the data were descriptive analysis and inferential analysis. Descriptive analysis was used to find out the mean, median, mode, and standard deviation of the scores of the reading test. Inferential analysis used was ANOVA $2 \times 2$.

Table 1

The Design of Analysis of Variance (2x2)

\begin{tabular}{|l|c|c|}
\hline $\begin{array}{l}\text { Strategy of } \\
\text { Teaching }\end{array}$ & $\begin{array}{c}\text { Instagram } \\
\text { Activity } \\
\left(\mathbf{A}_{1}\right)\end{array}$ & $\begin{array}{c}\text { Expository } \\
\text { Teaching } \\
\text { Strategy } \\
\left(\mathbf{A}_{2}\right)\end{array}$ \\
$\begin{array}{l}\text { A) } \\
(\mathbf{B})\end{array}$ & & \\
\hline High $\left(\mathrm{B}_{1}\right)$ & $\mathrm{A}_{1} \mathrm{~B}_{1}(50 \%)$ & $\mathrm{A}_{2} \mathrm{~B}_{1}(50 \%)$ \\
\hline Low $\left(\mathrm{B}_{2}\right)$ & $\mathrm{A}_{1} \mathrm{~B}_{2}(50 \%)$ & $\mathrm{A}_{2} \mathrm{~B}_{2}(50 \%)$ \\
\hline
\end{tabular}

\section{RESULT AND DISCUSSIONS}

\section{Data Description}

In the experimental group, the mean score of the pre-test was 6.292 with standard deviation of 0.6064 . Meanwhile, improvement was shown with the mean score of the post-test 7.437 with standard deviation 1.6766 .

In the control group, the mean score of the pre-test was 6.20 with standard deviation was 0.7071 . Meanwhile, the mean score of the post-test was 6.18 with standard deviation was 0.4052 .

The different mean score shows that the students showed no improvement in post- test. Table 2 shows the descriptive statistics of speaking achievement of both experimental and control group. 
Table. 2

The Descriptive Statistic of Pre-Test and Post-Test of Speaking Achievement in Experimental and Control Group

\begin{tabular}{|lcccccccc|}
\hline \multicolumn{1}{|c}{ Class } & \multicolumn{4}{c}{ Pretest } & \multicolumn{3}{c|}{ Posttest } \\
\cline { 2 - 9 } & Max & Min & mean & Std.Dev & Max & Min & mean & Std.Dev \\
\hline Experimental & 8 & 6 & 7.92 & 0.60 & 13.5 & 6 & 7.43 & 1.67 \\
& & & & 0.4 & & & & 6 \\
\hline Control & 9 & 6 & 6.29 & 0.70 & 7.5 & 6 & 6.28 & 0.41 \\
& & & & 71 & & & & 2 \\
\hline
\end{tabular}

Result of Interaction Effects of Instagram Activity and Motivation on Speaking Achievement

Based on the test of betweensubject effects (See Table 3 below), the

Table. 3

Test of between Subjects Effects

\begin{tabular}{|l|r|r|rrr|r|}
\hline \multicolumn{1}{|c}{ Source } & $\begin{array}{c}\text { Type III } \\
\text { Sum of } \\
\text { Squares }\end{array}$ & DF & $\begin{array}{c}\text { Mean } \\
\text { Square }\end{array}$ & F & Sig. & $\begin{array}{c}\text { Partial } \\
\text { Eta } \\
\text { Squared }\end{array}$ \\
\hline Corrected Model & $378,374^{\mathrm{a}}$ & 3 & 126,125 & 5,064 &, 004 &, 252 \\
\hline Intercept & 35052,663 & 1 & 35052,663 & 1407,502 &, 000 &, 969 \\
\hline STRATEGY & 350,735 & 1 & 350,735 & 14,083 &, 000 &, 238 \\
\hline MOTIVATION & 38,736 & 1 & 38,736 & 1,555 &, 000 &, 033 \\
\hline STRATEGY* & 17,882 & 1 & 17,882 & .718 &, 001 &, 016 \\
MOTIVATION & 1120,687 & 45 & 24,904 & & & \\
\hline Error & 40590,000 & 49 & & & & \\
\hline Total & 1499,061 & 48 & & & & \\
\hline Corrected Total & & & & & & \\
\hline
\end{tabular}

\section{Result of Feedbacks from the Students}

The sample students responded the significance values of motivation (.219) was higher than 0.05 . It indicates that there was significant effect of motivation on speaking achievement.

two open ended questions given. The followings were the results of their feedbacks (Table 4).

Table 4

Feedbacks from Overall Students

\begin{tabular}{|c|c|c|}
\hline No. & Questions & Feedbacks \\
\hline 1. & $\begin{array}{l}\text { What do you } \\
\text { expect your } \\
\text { instructor will do } \\
\text { to help you in } \\
\text { speaking? }\end{array}$ & $\begin{array}{l}\text { 1. Instructor should give attention to } \\
\text { individual student in English } \\
\text { speaking. } \\
\text { 2. Instructor's opinion is important. } \\
\text { 3. Instructor could enlarge students' } \\
\text { vocabularies motivation and }\end{array}$ \\
\hline
\end{tabular}




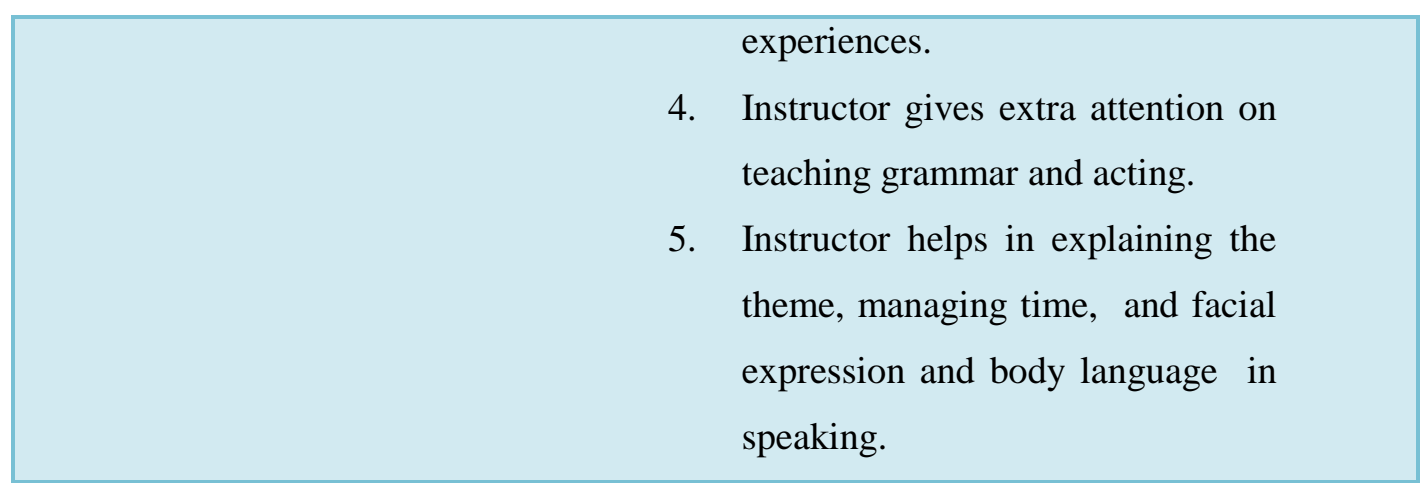

\section{DISCUSSION}

Based on the results of the study, some interpretations can be presented. First, the result of paired sample t-test of speaking achievement in experimental group showed that there was a significant difference in paired sample t-test. In pretest, the result was dominated by poor and fair categories, but after the interventions, it was improved and changed into good category in several students speaking results. The increasing could be seen from the mean scores of experimental group after pre-test and post-test. The improvement was not that very high, indeed. The students had worked very hard to be in that category since their English proficiency was very low. In pre-test, some students' speaking results were unsatisfactory. There were several students who only performed and stated their script part with no meaningful intention in it. After several treatments of Instagram activity were conducted, their knowledge and ability of speaking performance improved. In post-test, the students could perform in better speaking results. Moreover, there was significant difference in speaking achievement between these two tests of the experimental.

Whereas there was no significant difference in paired sample t-tests of speaking achievement in control group. In pre-test, the result was dominated by poor and fair categories, but in the post-tests, the students' post-tests were still dominated by poor and fair categories. The findings of the data showed that there was no progress from the total scores of pre-test and posttests in the control group. The means score of the post-tests in control group was even lower than the pre-tests.

The results of Independent Sample t-tests of speaking achievement showed that there was a significant difference in independent sample t-tests. The finding of the data showed progress from the total scores of pre-test and post-test of both experimental and control groups. The increasing could be seen from the mean scores of both experimental and control 
groups after pre-test and post-test. Moreover, there was a significant difference in speaking achievement between those two groups. The students in the experimental group got a significant progress. In post-test, the students in the experimental group could show their effort in speaking test independently. It means that the application of Instagram activity in teaching speaking could enhance the students' speaking achievement of the experimental group.

Second, there was interaction effect of the activity used and students' speaking motivation on their speaking achievement. In other words, it could be stated that Instagram activity affected students` achievement. It was possibly due to the fact that Instagram is a phenomenon in social media and it is the one closest to the students nowadays.

\section{CONCLUSION}

This study gave several conclusions that could be drawn, they are as follows:

1. Teachers at any level should create convenient and enjoyable learning situation. Teachers need to do variation in delivering learning materials to their students.

2. Instagram Activity gave significant contribution in students learning as it is able to motivate them to improve their knowledge and capability, in this study, it could improve the students` English speaking skill.

3. It is certain that Instagram Activity of teaching could be applied in English Speaking class. It as also certain that it could be applied in every subject. It only takes teachers` creativity in doing modification to their subjects.

\section{Recommendation}

Speaking by applying Instagram Activity could improve students motivation in studying English. This motivation could lead the students to perform their subjects better. It is due to the reason that in Instagram as famous social media has enjoyable activities that attract students to find out more about the subject.

\section{REFERENCES}

Arsjad, Maidar G, \& Mukti U.S. (1988).

Pembinaan Kemampuan Berbicara Bahasa Indonesia. Jakarta: Erlangga.

Brown, H.D. (1994). Teaching by principles: an interactive approach to language pedagogy. Englewood Cliffs, NJ: Prentice Hall Regents.

Brown,H. D. (2001). Teaching by Principle An Interactive Approach to Language Pedagogy. San Francisco: Longman 
Chaney, A.L., \& T.L. Burk. (1998). Teaching oral communication in grades $K-8$. Boston: Allyn \& Bacon.

Christensen, L.B. (1977). Experimental Methodology. London: Allyn and Bacon Inc.

Cohen, L., Manion, L., \& Morrison, K. (2007). Research methods in Education. Sixth Edition. New York: Routledge.

Crowley, B. (2015). Connecting a Classroom: Reflections on Using Social Media with My Students. Retrieved from:

http://www.edweek.org/tm/articl es/2015/09/09/connecting-aclassroom-refl ections-on-usingsocial.html>

Diamond , S, (2013),“The Visual Marketing Revolution: 26 Rules to Help Social Media Marketers Connect The Dots”, Que Publishing. Retrieved from:Http://adage.com/article/digita 1/instagram-publishing-a-adday/245427/

Elliot, S. (2000). Educational Psychology: Effective Teaching Effective Learning. USA:McGraw Hill Company.

Fraenkel, J, R., \& Wallen, N. E. (1993) How to design and evaluate research in education: 2nd
Edition. New York: McGrawHill Inc.

Handayani, F. (2016). Instagram as a teaching tool? Really? Paper presented on ISELT 4 or International Seminar on English Language and Teaching 4.

Hermann, J. (2014). The Ultimate Beginner`s Guide to Instagram. https://jennstrends.com/wpcontent/uploads/2014/05/The-

Ultimate-Beginners-Guide-ToInstagram.pdf

Kelly, R. (2015). An exploration of Instagram to Develop ESL Learners` Writing Skills. A Dissertation submitted in partial fulfillment of the requirements for the degree of MA in the teaching of English to Speakers of Other Languages (TESOL). Retrieved from:

https://englishagenda.britishcouncil. org/sites/default/files/attachments/di ssertation_for_publication_ulster_u niversity.pdf

McDonald, F. (1960). Educational psychology. San Fransisco: Walth Publishing.

Sardiman. (2007). Interaksi dan Motivasi Belajar Mengajar. Jakarta: Raja Grafindo Persada 
Spencer, J. (2012). Ten ideas for using

Instagram in the classroom.

Retrieved from:

http://www.educationrethink.com

/2012/07/ten-ideasfor-using-

instagram-in.html.

Tarigan, D. (1995). Materi Pokok

Pendidikan Bahasa Indonesia.

Jakarta: Depdikbud.

Ting, H., Run, E.C.D., Ming, W.M.P., \& Choo, S.L.Y. (2015). Beliefs about the Use of Instagram: An Exploratory Study. International Journal of Business and Innovation. Vol 2, Issue 2. Retrieved from: https://www.researchgate.net/public ation/272026006_Beliefs_about_the _Use_of_Instagram_An_Explorator y_Study.

Wally, E. \& Koshy, S. (2014). The use of Instagram as a marketing tool by Emirati female entrepreneurs: an exploratory study'. 29th International Business Research Conference, World Business Institute Australia, Australia, pp. 119. 
